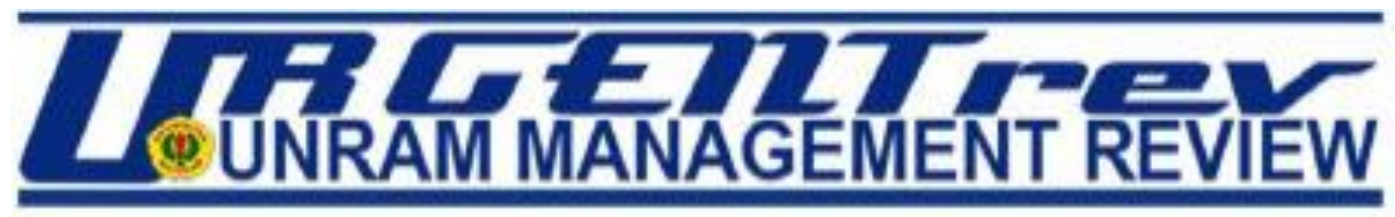

Vol. 1 No. 1 Oktober 2021

e.ISSN. 2809-4263

urgentrev.unram.ac.id

\title{
PENGARUH COUNTRY OF ORIGIN, BRAND IMAGE DAN PERCEIVED QUALITY TERHADAP MINAT BELI SMARTPHONE OPPO
}

\author{
Ni Made Eka Kesuma Sari Manten, Sulhaini, Baiq Handayani Rinuastuti \\ Fakultas Ekonomi dan Bisnis \\ Universitas Mataram \\ Email : madheeka13@gmail.com
}

DOI: https://doi.org/10.29303/ju.v1i1.37

\begin{abstract}
ABSTRAK
Penelitian ini bertujuan untuk mengetahui pengaruh Country Of Origin, Brand Imagedan Perceived Quality terhadap minat beli smartphone OPPO. Jenis penelitian ini adalah penelitian kuantitatif. Populasi pada penelitian ini adalah mahasiswa yang mengetahui negara asal OPPO. Metode pengambilan sampel adalah purposive sampling dengan jumlah responden sebanyak 115 orang. Data dikumpulkan dengan kuesioner yang telah di uji validitas dan reliabilitasnya. Teknik analisis data yang digunakan adalah regresi berganda menggunakan SPSS versi 23. Hasil penelitian ini menunjukkan bahwa terdapat dua dari tiga variabel independen yang mempunyai pengaruh positif dan signifikan terhadap minat beli smartphone OPPO, dua variabel itu adalah Country Of Origin dan Perceived Quality sementara satu variabel menunjukkan hasil positif tetapi tidak signifikan yaitu variabel Brand Image. Adapun rekomendasi yang dapat diberikan adalah Perusahaan OPPO disarankan meningkatkan image dari merek OPPO tersebut dengan cara membangun dengan baik brand identity (indentitas merek) yaitu identitas fisik dari merek OPPO tersebut seperti logo, warna dan kemasan .
\end{abstract}

Kata kunci: Country of Origin, Brand Image, Perceived Quality, Minat Beli

\begin{abstract}
This study aims to determine the effect of Country Of Origin, Brand Image and Perceived Quality on buying interest in OPPO smartphones. This type of research is quantitative research. The population in this study are students know their country of origin. The sampling method was purposive sampling with a total of 115 respondents. Data were collected using a questionnaire that has been tested for validity and reliability. The data analysis technique used is multiple regression using SPSS version 23. The results of this study indicate that there are two out of three independent variables that have a positive and significant influence on buying interest in OPPO smartphones, the two variables are Country Of Origin and Perceived Quality, while one variable shows positive results but not significant, namely the Brand Image variable.The recommendations that can be given are that the OPPO Company is advised to improve the image of the OPPO brand by building a good brand identity, namely the physical identity of the OPPO brand such as the logo, color and packaging.
\end{abstract}

Keywords: Country of Origin, Brand Image, Perceived Quality, Purchase Interest 


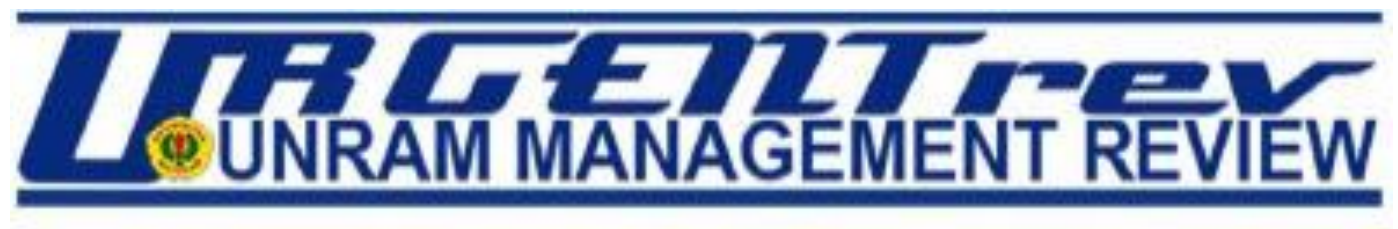

\section{PENDAHULUAN}

Saat ini terjadi perkembangan yang semakin pesat di bidang transportasi, komunikasi dan teknologi. Individu semakin mudah berinteraksi dan berkomunikasi tanpa tatap muka langsung. Perubahan cara gaya hidup dan perilaku masyarakat sejalan dengan perkembangan teknologi komunikasi yang semakin canggih.

Perkembangan teknologi ini dapat dilihat melalui gaya hidup masyarakat yang mulai berubah dengan maraknya smartphone yang bermunculan, serta jaringan internet yang semakin lama dapat diakses dengan mudah melalui smartphone masing-masing individu.

Smartphone merupakan salah satu hasil dari perkembangan teknologi informasi yang sangat dekat dengan kehidupan manusia. Perkembangan smartphone saat ini sangat bervariasi, banyak perusahaan dan merek smartphone yang memiliki keunggulan dan fitur tersendiri untuk memenangkan persaingan. Smartphone memiliki beberapa fungsi yang dapat membantu masing-masing pengguna seperti misalnya mengirim pesan instant, penggunaan aplikasi, mendapatkan informasi melalui jaringan $\mathrm{WiFi}$ atau Global Position System (GPS) dan hiburan (King, 2011 pada Ting et al., 2011).

Canalys merilis data yang cukup mengejutkan terkait pangsa pasar smartphone di tanah air. Untuk pertama kalinya dalam sejarah pada tahun 2019, OPPO berhasil menguasai pangsa pasar ponsel di Indonesia, merebut posisi nomor satu yang selama ini dipegang oleh Samsung. Pencapaian market share penjualan tersebut tidak terlepas dari adanya keinginan masyarakat yang cukup tinggi terhadap merek tersebut dan komitmen OPPO yang terus menghadirkan fitur-fitur perangkat kelas premium untuk berada pada perangkat kelas menengah menjadi kunci sukses OPPO menguasai pasar Indonesia.

Pada bulan April tahun 2013, OPPO smartphone pertama kali memperkenalkan dirinya di Indonesia dengan produknya OPPO Find 5 tepatnya pada 17 April 2013. Keyakinan OPPO dengan produknya tak hanya putus pada Find 5, di tahun yang sama perusahaan juga menghadirkan seri lainnya yang digadangkan dengan nama Find Way. Pada tahun 2014, OPPO Indonesia mulai melakukan transisi total ke handset $4 \mathrm{G}$ LTE, menutup tahun 2014, OPPO mengeluarkan dua produk yakni N3 dan R5. OPPO R5, kala itu dikenal dengan strategi sebagai ponsel paling tipis di dunia. Sementara OPPO N3 menjadi seri yang hadir dengan inovasi kamera berputar otomatis hingga 206 derajat). Selanjutnya di 2016, OPPO kembali mengeluarkan produk baru dengan rangkaian F1, F1 Plus dan F1s di bawah label F series (Sukma, 2016).

Lokasi dimana produk dihasilkan (made-in effect) akan mempengaruhi minat beli maupun keputusan pembelian oleh konsumen. Suatu negara akan dipersepsikan mempunyai reputasi yang eksklusif atas suatu produk tertentu. Menurut Lin dan Kao (2004), Country of Origin akan menciptakan suatu persepsi tertentu akan suatu merek produk, dimana persepsi bisa positif maupun negatif, hingga level berikutnya persepsi positif akan mendorong terciptanya pembelian aktual. Meningkatnya globalisasi ekonomi mengakibatkan turunnya hambatan perdagangan antar negara, sehingga ketersediaan produk asing di pasar lokal semakin luas. Dalam keadaan demikian, banyak produk dan jasa dievaluasi dengan memperhatikan $\mathrm{COO}$ sebagai pembeda kompetitif yang potensial di pasar lokal masing-masing negara. Simamora (2000) mengatakan bahwa negara asal (country of origin) juga memiliki pengaruh besar pada persepsi terhadap kualitas produk. Salah satu efek yang dimiliki COO terhadap calon konsumen, yakni seringkali calon konsumen memiliki persepsi bahwa perusahaan atau merek tertentu berasosiasi dengan negara tertentu. 


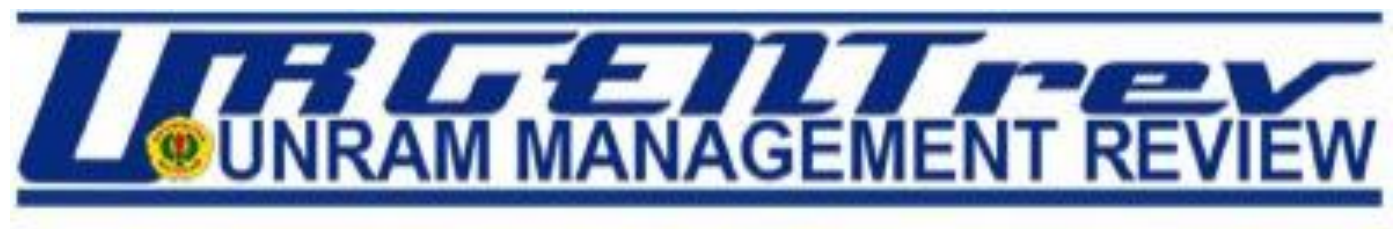

Pada awal kemunculan OPPO, tidak sedikit promotor (frontliner) OPPO smartphone menyatakan bahwa OPPO merupakan produk buatan Amerika, Italia, Belgia, Denmark, atau Korea kepada calon pembelinya (www.ponselmu.com). Padahal perusahaan OPPO didirikan pada tahun 2004 di Dongguan, Guangdong, Republik Rakyat Cina oleh Tony Chen. Tak hanya itu, adanya stigma negatif oleh masyarakat Indonesia yang memandang sebelah mata produk smartphone buatan Cina. Hal ini terlihat dari masalah pabrikan motor asal China yang menjual produknya seakan meniru produk lain, sehingga berdampak pada industri smartphone. Untuk mengubah padangan tersebut, OPPO memiliki cara tersendiri yaitu berupaya menunjukkan kualitas produknya lewat smartphone premium. Namun tidak bisa diragukan atau didebatkan lagi adalah fakta bahwa brand asal Tiongkok benarbenar semakin mendominasi penjualan smartphone di tanah air.

Selain itu brand image juga dijadikan sebagai acuan dalam memilih produk. Brand image merupakan seperangkat keyakinan, ide, kesan yang dimiliki seseorang terhadap suatu merek (Simamora, 2004). Apabila para konsumen beranggapan bahwa merek tertentu secara fisik berbeda dari merek pesaing citra merek tersebut akan melekat secara terusmenerus sehingga dapat meciptakan loyalitas konsumen (Rangkuti,2004).

$$
\text { Kesukesesan OPPO dalam }
$$

mepertahankan brand image yang dimilikinya tidak terlepas dari inovasi dan mengikuti trend permintaan pasar, seperti trend smartphone dengan layar besar dan memiliki kamera yang mampu menghasilkan foto selfie dengan jernih (OPPO F5). Smartphone OPPO juga dikenal dengan jargon "Selfie Expert" yang dibenamkan pada tiap produk-produk andalannya. Sebagai contoh dapat dilihat dari salah satu produk OPPO yaitu seri F1, yang menguatkan pada sisi kamera meski tetap mengedepankan desain dan spesifikasi yang mumpuni.
Keputusan untuk membeli suatu produk juga dipengaruhi oleh perceived quality. perceived quality merupakan penilaian konsumen terhadap kualitas produk secara keseluruhan berkenaan dengan karakteristik produk yang diharapkan (Ambrawati,2006). Semakin tinggi nilai yang diperoleh oleh konsumen maka minat beli produk tersebut juga semakin tinggi. Di Indonesia, produk OPPO memang sudah terkenal nama dan kualitasnya. Banyak produk OPPO yang ketika diperkenalkan pertama kali langsung mendapatkan banyak tanggapan positif dari konsumen. Salah satu produknya yaitu OPPO A9, dimana para konsumen penasaran dengan spesifikasi dan teknologi apa yang dimiliki OPPO A9 tersebut.

Berkembangnya industri telekomunikasi yang cepat, OPPO harus mampu dalam mengembangkan brand image dan kualitas produk agar mampu bersaing dengan pesaing lainnya. Melakukan pengembangan brand image dan kualitas produk diharapkan dapat mempengaruhi konsumen dalam mengambil langkah untuk melakukan keputusan pembelian. Adanya fenomena kesuksesan smartphone OPPO yang baru memasuki pasar smartphone di Indonesia berhasil menjadi top brand peringkat $1 \mathrm{di}$ tahun 2019, sehingga merek smartphone OPPO dianggap menarik menjadi subjek penelitian.

\section{RUMUSAN MASALAH}

Indonesia termasuk negara dengan pengguna smartphone terbesar ke 4 di dunia. Hal ini membuat para produsen smartphone berlomba-lomba untuk menguasai pasar ponsel di Indonesia termasuk salah satunya produsen dari negara Cina yang tidak lama ini muncul dengan mengahadirkan produk smartphone yaitu smartphone OPPO. OPPO merupakan salah satu brand smartphone global yang sukses menggarap pasar Indonesia. Tidak dapat diragukan lagi bahwa brand asal Cina benar-benar semakin mendominasi penjualan 


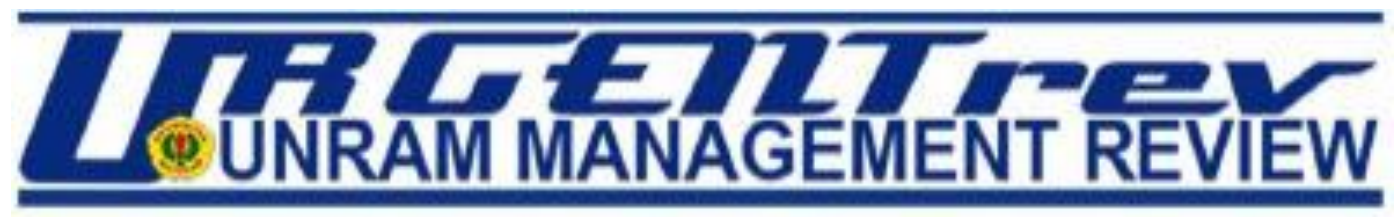

smartphone di Indonesia, hal ini tidak terlepas dari keinginan konsumen yang cukup tinggi terhadap merek tersebut dibandingkan dengan merek lainnya dan komitmen OPPO yang terus menghadirkan kualitas camera terbaik serta pendekatan pada sisi desain dan penyajian warna perangkat yang tampil beda diyakini dapat menjadi daya tarik utama menarik konsumen, namun belum diketahui apakah country of origin, brand image dan perceived quality yang menyebabkan konsumen tertarik terhadap smartphone OPPO di Indonesia.

\section{PERTANYAAN PENELITIAN}

1. Apakah Country of Origin berpengaruh terhadap Minat Beli smartphone OPPO?

2. Apakah Brand Image berpengaruh terhadap Minat Beli smartphone OPPO?

3. Apakah Perceived Quality berpengaruh terhadap Minat Beli smartphone OPPO?

\section{KAJIAN PUSTAKA}

\section{Minat Beli}

Menurut Yathi dan Jatra (2015) minat beli adalah suatu tahapan awal untuk mempertimbangkan atau membuat keputusan dalam memilih suatu produk atau jasa. Minat beli menciptakan suatu motivasi yang akan terus terekam dalam pikiran dan menjadi suatu keinginan yang sangat kuat yang pada akhirnya ketika akan memenuhi kebutuhannya mereka akan merealisasikan apa yang ada dalam pikirannya.

Menurut Assael (2002), ada 2 faktor yang mempengaruhi minat beli konsumen, diantaranya yaitu :

1) Lingkungan, yakni lingkungan disekitar bisa mempengaruhi minat beli konsumen dalam pemilihan suatu produk tertentu.

2) Stimulus pemasaran, yakni pemasaran berupaya menstimulus konsumen sehingga bisa menarik minat beli konsumen.

Menurut Abdurachman (2004), terdapat beberapa faktor yang mempengaruhi minat beli, yaitu sebagai berikut:

1. Faktor kualitas

2. Faktor brand/merek

3. Faktor kemasan

4. Faktor harga

5. Faktor ketersediaan barang

6. Faktor acuan

Menurut Ferdinand (2014), minat beli dapat diidentifikasi melalui indikatorindikator sebagai berikut :
a. Minat transaksional
b. Minat refrensial
c. Minat preferensial
d. Minat ekspolaratif

\section{Country Of Origin}

Menurut Shamidra dan Saroj (2011), Country of Origin sering dikaitkan dengan kualitas produk. Konsumen akan menggunakan Country of Origin sebagai standar kualitas suatu produk sebelum produk tersebut dibeli.

Menurut Hsieh et al. (2004) dalam Demirbag et al. (2010) pada dasarnya, citra negara dalam perspektif pemasaran dapat didefinisikan pada tiga tingkat, yaitu

1) Overall country image (citra negara keseluruhan)

2) Aggregate product country image (citra negara asal produk keseluruhan).

3) Specific product country image (citra negara asal dilihat pada kategoriproduk tertentu.

Indikator Country of Origin menurut Yasin, Nasser dan Osman (2007) yaitu:

1. Inovasi negara dalam berproduksi,

2. Tingkat kemajuan teknologi negara asal merek,

3. Desain produksi,

4. Kreativitas berproduksi,

5. Kualitas produksi,

6. Prestise yang dimiliki negara asal merek, dan

7. Citra negara asal merek sebagai negara maju.

\section{Brand Image}


Kotler dan Keller (2012:768) mendefinisikan brand image sebagai sekumpulan persepsi dan kepercayaan yang dimiliki oleh pelanggan terhadap suatu brand yang direfleksikan melalui asosiasiasosiasi yang ada dalam ingatan pelanggan.

$$
\text { Menurut Keller (2013:97) }
$$

dimensi-dimensi utama membentuk citra sebuah merek tertuang dalam berikut ini:

1. Brand Identity (identitas Merek)

2. Brand Personality (Personalitas Merek).

3. Brand Association (Asosiasi Merek).

4. Brand Attitude and Behavior (sikap dan perilaku merek).

5. Brand Benefit and Competence (Manfaat dan Keunggulan Merek).

\section{Perceived Quality}

Menurut Aaker (1997) persepsi kualitas (perceived quality) dapat didefinisikan sebagai persepsi pelanggan terhadap keseluruhan kualitas atau keunggulan suatu produk atau jasa layanan berkaitan dengan apa yang diharapkan oleh pelanggan.

Dimensi persepsi kualitas mengacu pada pendapat David. A. Garvin dalam Durianto et. al (2001), dimensi persepsi kualitas terbagi tujuh yaitu:

1) Kinerja

2) Pelayanan

3) Ketahanan

4) Keandalan

5) Karateristik produk

6) Kesesuaian dengan spesifikasi

7) Hasil

\section{HUBUNGAN ANTAR VARIABEL}

1. Pengaruh Country of Origin Terhadap Minat Beli

Menurut Rafida (2015) tentang, "Pengaruh Country of Origin Terhadap Minat Beli dengan Perceived Quality sebagai Variabel Intervening", menunjukkan bahwa variabel Country of Origin memiliki pengaruh positif namun tidak signifikan terhadap minat beli Oppo smartphone pada pengunjung Artomoro Seluler Madiun. Dari penelitian tersebut penulis menduga bahwa ada hubungan antara variabel country of origin terhadap minat beli. Atas dasar tersebut maka dapat disusun suatu hipotesis sebagai berikut :

H1 : Semakin baik country of origin maka semakin tinggi minat beli smartphone OPPO

2. Pengaruh Brand Image Terhadap Minat Beli

Menurut Simamora (2004), brand image merupakan seperangkat keyakinan, ide, kesan yang dimiliki seseorang terhadap suatu merek. Menurut penelitian Mendrofa (2012) mengenai, "Effect of ProductKnowledge and Brand Image to Purchase Intention with HP Laptop Brand Price Discounts as Variables Moderated in Surabaya", menyatakan bahwa brand image memiliki pengaruh yang signifikan terhadap minat beli laptop merek HP. Dari penelitian tersebut penulis menduga bahwa ada hubungan antara variabel country of origin terhadap minat beli. Atas dasar tersebut maka dapat disusun suatu hipotesis sebagai berikut:

H2 : Semakin baik brand image maka semakin tinggi minat belismartphone OPPO.

3. Pengaruh Perceived Quality Terhadap Minat Beli

Menurut Indrayani dan Nurcaya (2014) yang melakukan penelitian mengenai, "Peran Persepsi Kualitas Produk dalam Memediasi Pengaruh Gaya Hidup Terhadap Niat Beli Handphone Samsung Galaxy di Kota Denpasar", menyatakan bahwa persepsi kualitas berpengaruh positif dan signifikan terhadap niat beli. Dari penelitian tersebut penulis menduga bahwa ada hubungan antara variabel country of origin terhadap minat beli. Atas dasar tersebut maka dapat disusun suatu hipotesis sebagai berikut :

H3 : Semakin baik perceived quality maka semakin tinggi minat beli smartphone OPPO .

METODE PENELITIAN 
Penelitian ini menggunakan metode riset kausal dengan pendekatan secara kuantitatif, artinya riset ini bertujuan mengidentifikasikan kesimpulan sebab akibat atau hubungan antara variabel country of origin, brand image dan perceived quality dengan variabel minat beli smartphone OPPO. Penelitian ini dilakukan di seluruh Indonesia.

Metode pengumpulan data yang digunakan dalam penelitian ini adalah sampel survey yaitu survey yang dilakukan pada sebagian populasi (sampel) dimana metode ini diakukan dengan cara online sampel survey. Populasi pada penelitian ini adalah mahasiswa seluruh Indonesia yang mengenal dan mengetahui smartphone OPPO. Sampel pada penelitian ini berjumlah 115 sampel responden. Dalam penelitian ini, teknik pengambilan sampel dilakukan dengan menggunakan metode purposive sampling yaitu metode penetapan responden untuk dijadikan sampel berdasarkan kriteria-kriteria tertentu (Siregar, 2016:148) . Adapun kriteria sampel dalam penelitian ini adalah Mahasiswa yang mengetahui negara asal OPPO. Teknik pengumpulan data pada penelitian ini menggunakan media google form dan disebarkan secara online.

\section{HASIL DAN PEMBAHASAN \\ Karakteristik Responden}

Hasil penelitian yang dilakukan terhadap 115 orang responden, dapat diketahui tentang gambaran umum karakteristik responden. Uraian karakteristik responden ini menyangkut Jenis Kelamin, Usia, Provinsi Asal, Perguruan Tinggi, Fakultas, Pendidikan yang sedang ditempuh, Uang saku per bulan, dan Pekerjaan Orang Tua. 


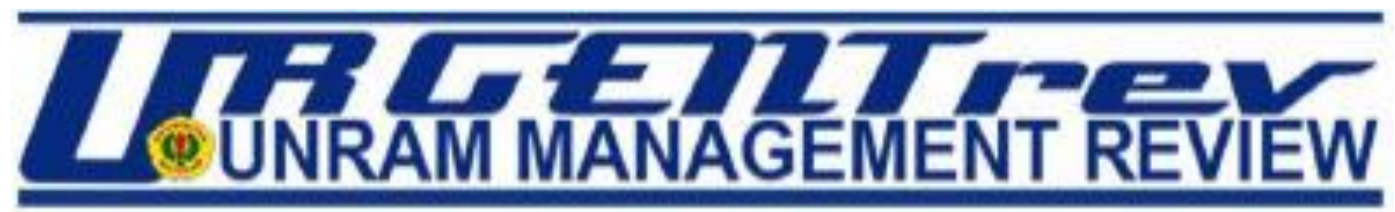

Vol. 1 No. 1 Oktober 2021

๑.ISSN. 2809-4263

urgentrev.unram.ac.id

Tabel 1 Hasil Penelitian

\begin{tabular}{|c|c|c|c|c|}
\hline No & Karakteristik & & Jmlh & Persentase \\
\hline \multirow{3}{*}{1} & Jenis Kelamin & $\mathrm{L}$ & 42 & $36,52 \%$ \\
\hline & & $\mathrm{P}$ & 73 & $63,48 \%$ \\
\hline & Total & & 115 & \\
\hline \multirow[t]{3}{*}{2} & Usia & 17-23 Tahun & 108 & $93,91 \%$ \\
\hline & & 24-30 Tahun & 7 & $6,09 \%$ \\
\hline & Total & & 115 & \\
\hline \multirow[t]{6}{*}{3} & Provinsi Asal & NTB & 111 & $96,52 \%$ \\
\hline & & BIMA & 1 & $0,87 \%$ \\
\hline & & BALI & 1 & $0,87 \%$ \\
\hline & & JAKARTA & 1 & $0,87 \%$ \\
\hline & & JAWA & 1 & $0,87 \%$ \\
\hline & & & 115 & \\
\hline \multirow[t]{11}{*}{4} & Perguruan Tinggi & Universitas Mataram & 96 & $83.47 \%$ \\
\hline & & $\begin{array}{l}\text { Akademi Komuntas } \\
\text { Negeri Lombok Barat }\end{array}$ & 1 & $0,87 \%$ \\
\hline & & POLTEKKES & 6 & $5,22 \%$ \\
\hline & & $\begin{array}{l}\text { IAHN Gde Pudja } \\
\text { Mataram }\end{array}$ & 4 & $3,48 \%$ \\
\hline & & Universitas Brawijaya & 1 & $0,87 \%$ \\
\hline & & Universitas Terbuka & 1 & $0,87 \%$ \\
\hline & & $\begin{array}{l}\text { Universitas } \\
\text { Bumigora }\end{array}$ & 2 & $1,74 \%$ \\
\hline & & Universitas Saraswati & 1 & $0,87 \%$ \\
\hline & & UIN Malang & 2 & $1,74 \%$ \\
\hline & & $\begin{array}{l}\text { Unversitas Teknologi } \\
\text { Mataram }\end{array}$ & 1 & $0,87 \%$ \\
\hline & Total & & 115 & \\
\hline \multirow[t]{10}{*}{5} & Fakultas & FEB & 70 & $60,87 \%$ \\
\hline & & FKIP & 17 & $14,78 \%$ \\
\hline & & TATA BOGA & 1 & $0,87 \%$ \\
\hline & & TEKNIK & 4 & $3,48 \%$ \\
\hline & & MIPA & 2 & $1,74 \%$ \\
\hline & & $\begin{array}{l}\text { HUKUM } \\
\text { ANALISIS } \\
\text { KESEHATAN }\end{array}$ & $\begin{array}{l}6 \\
6\end{array}$ & $\begin{array}{l}5,22 \% \\
5,22 \%\end{array}$ \\
\hline & & PERTANIAN & 4 & $3,48 \%$ \\
\hline & & FISIPOL & 1 & $0,87 \%$ \\
\hline & & KEDOKTERAN & 4 & $3,48 \%$ \\
\hline & Total & & 115 & \\
\hline \multirow[t]{5}{*}{6} & $\begin{array}{l}\text { Pendidikan yang } \\
\text { sedang di tempuh }\end{array}$ & D1 & 0 & $0 \%$ \\
\hline & & $\mathrm{D} 2$ & 1 & $0,87 \%$ \\
\hline & & D3 & 5 & $4,38 \%$ \\
\hline & & S1 & 109 & $94,78 \%$ \\
\hline & Total & & 115 & \\
\hline 7 & $\begin{array}{lll}\begin{array}{l}\text { Uang } \\
\text { bulan }\end{array} & \text { Saku per } \\
\end{array}$ & $<\operatorname{Rp} 500.000$ & 60 & $52,17 \%$ \\
\hline
\end{tabular}




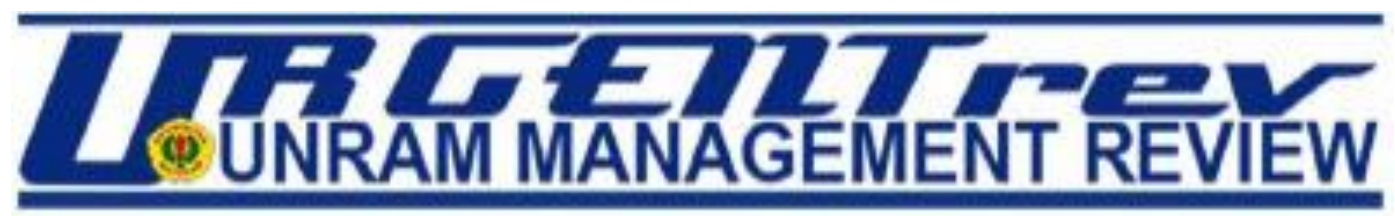

Vol. 1 No. 1 Oktober 2021

๑.ISSN. 2809-4263

urgentrev.unram.ac.id

\begin{tabular}{|c|c|c|c|c|}
\hline & & $\begin{array}{l}\mathrm{Rp} \quad 500.000-\mathrm{Rp} \\
1.000 .000\end{array}$ & 43 & $37,39 \%$ \\
\hline & & $\begin{array}{l}\mathrm{Rp} 1.000 .000-\mathrm{Rp} \\
1.500 .000\end{array}$ & 7 & $6,09 \%$ \\
\hline & & $\begin{array}{l}\mathrm{Rp} 1.500 .000-\mathrm{Rp} \\
2.000 .000\end{array}$ & 0 & $0 \%$ \\
\hline & & $>\operatorname{Rp} 2.000 .000$ & 5 & $4,38 \%$ \\
\hline & Total & & 115 & \\
\hline 8 & $\begin{array}{l}\text { Pekerjaan Orang } \\
\text { Tua }\end{array}$ & Pegawai Swasta & 31 & $26,96 \%$ \\
\hline & & PNS & 36 & $31,30 \%$ \\
\hline & & Wirausaha & 48 & $41,74 \%$ \\
\hline & Total & & 115 & \\
\hline
\end{tabular}

\section{ANALISIS DATA}

Sebelum menggunakan analisis regresi linier berganda dilakukan uji asumsi klasik yaitu uji normalitas dan uji multikolinearitas. Dari uji normalitas diperoleh hasil bahwa data terdistribusi normal. Dari uji multikolinearitas disimpulkan tidak terdapat masalah multikolinearitas diantara sesama variabel bebas dalam model regresi yang terbentuk. Hasil regresi linier berganda dapat dilihat pada Tabel dibawah ini.

Tabel 2. Hasil regresi linier berganda

\begin{tabular}{|l|r|r|l|}
\hline & \multicolumn{2}{|c|}{$\begin{array}{c}\text { Unstandardized } \\
\text { Coefficients }\end{array}$} & $\begin{array}{l}\text { Standardized } \\
\text { Coefficients }\end{array}$ \\
\hline & \multicolumn{1}{|c|}{ Model } & \multicolumn{1}{c|}{$\begin{array}{c}\text { Std. } \\
\text { Error }\end{array}$} & \multicolumn{2}{|c|}{ Beta } \\
\hline (Constant) & 4,306 & 1,893 &, 268 \\
\hline $\begin{array}{l}\text { COUNTRY OF } \\
\text { ORIGIN }\end{array}$ &, 183 &, 077 &, 029 \\
\hline BRAND IMAGE &, 018 &, 048 &, 353 \\
\hline $\begin{array}{l}\text { PERCEIVED } \\
\text { QUALITY }\end{array}$ &, 208 &, 067 & \\
\hline
\end{tabular}

\begin{tabular}{|l|r|r|r|l|}
\hline Model & T hitung & T tabel & Sig. & Ket \\
\hline (Constant) & 2,274 & &, 025 & \\
\hline Country Of Origin & 2,362 & 1,981 &, 020 & Sig \\
\hline Brand Image &, 371 & 1,981 &, 711 & $\begin{array}{l}\text { Tidak } \\
\text { Sig }\end{array}$ \\
\hline Perceived Quality & 3,109 & 1,981 &, 002 & Sig \\
\hline
\end{tabular}

\section{PEMBAHASAN}

1. Pengaruh Country Of Origin (X1) terhadap minat beli. Berdasarkan persamaan diatas, maka diperoleh nilai koefisien regresi sebesar 0,268 , ini artinya untuk setiap peningkatan variabel country 


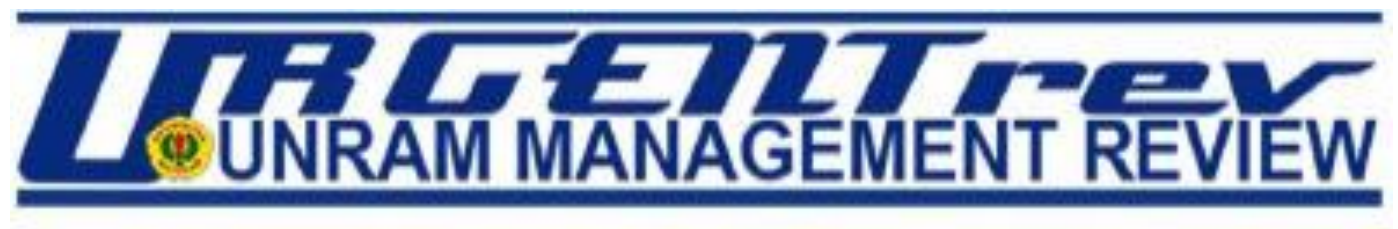

of origin sebesar 1 satuan maka akan meningkatkan minat beli sebesar 0,268 dengan asumsi variabel lain ( brand image dan perceived quality) dianggap tetap. Nilai t signifikan menunjukan bahwa Country of Origin berpengaruh signifikan terhadap Minat Beli atau semakin baik Country of Origin maka semakin tinggi Minat Beli. Menurut Lin dan Kao (2004), Country of Origin akan menciptakan suatu persepsi tertentu akan suatu merek produk, dimana persepsi bisa positif maupun negatif, hingga level berikutnya persepsi positif akan mendorong terciptanya pembelian aktual. Dari jawaban responden terhadap pernyataan mengenai Cina merupakan negara yang inovatif, Cina memiliki teknologi yang canggih, Cina mampu mendesain produk, Cina negara yang kreatif, Cina pembuat smartphone dengan kualitas yang tinggi, Cina memiliki reputasi merek yang baik, dan citra negara Cina sebagai negara maju dalam pembuat smartphone memiliki kesan yang baik. Responden memiliki pengetahuan yang besar dan paham dengan teknologi sehingga responden mempertimbangkan negara asal dari produk yang ingin dibeli. Semakin baik persepsi responden terhadap negara asal pembuat produk maka semakin tinggi minat responden untuk membeli produk dari negara tersebut. Hasil penelitian ini didukung oleh penelitian yang dilakukan oleh Dinata dan Hidayat (2015) mengenai, "Country of Origin dan Pengaruhnya Terhadap Persepsi Kualitas dan Minat Beli", menyatakan bahwa Country of Origin secara signifikan berpengaruh positif terhadap minat beli calon konsumen yang ingin membeli iPad di Indonesia.

2. Pengaruh Brand Image (X2) terhadap minat beli. Berdasarkan persamaan diatas, maka diperoleh nilai koefisien regresi sebesar 0,029, ini atrinya untuk setiap peningkatan variabel brand image sebesar 1 satuan maka akan meningkatkan minat beli sebesar 0,029 dengan asumsi variabel lain (country of origin dan perceived quality) dianggap tetap. Nilai t signifikan menunjukan bahwa brand image tidak berpengaruh signifikan terhadap Minat Beli. Dalam penelitian ini brand image responden terhadap smartphone OPPO tidak berpengaruh terhadap minat beli dikarenakan bahwa respondensaat ini tidak menekankan pada merek tetapi cenderung pada faktor lain seperti negara asal dari merek suatu produk dan kualitas dari suatu produk. Mahasiswa merupakan konsumen yang memiliki kemampuan dalam mengikuti perkembangan teknologi dan tidak ingin ketinggalan trend yang ada, sehingga dalam memutuskan untuk menggunakan suatu produk tidak menekankan pada merek tetapi lebih mementingkan ego dan gaya hidup, karena dengan menggunakan smartphone yang berteknologi tinggi dan sedang trend akan dapat meningkatkan kepercayaan diri. Responden dalam penelitian ini didominasi oleh responden laki-laki, dimana laki-laki tidak terlalu mementingkan merek tetapi lebih pada spesifikasi dari smartphone dikarenakan kebanyakan laki-laki menggunakan smartphone untuk kegiatan game. Selain itu citra merek OPPO dirasa belum cukup kuat untuk mendorong calon konsumen untuk melakukan pembelian. Hasil penelitian ini didukung oleh penelitian yang dilakukan oleh Desi Arista (2011), mengenai "Analisis pengaruh iklan, kepercayaan merek dan citra merek terhadap minat beli konsumen", menyatakan bahwa citra merek tidak signifikan terhadap minat beli sedangkan iklan dan kepercayaan merek berpengaruh signifikan terhadap minat beli.

3. Pengaruh perceived quality (X3) terhadap minat beli. Berdasarkan koefisien regresi sebesar 0,353, ini atrinya untuk setiap peningkatan variabel perceived quality sebesar 1 satuan maka akan meningkatkan minat beli sebesar 0,353 dengan asumsi variabel lain ( country of origin dan brand image) dianggap tetap. Nilai $\mathrm{t}$ signifikan menunjukan bahwa 


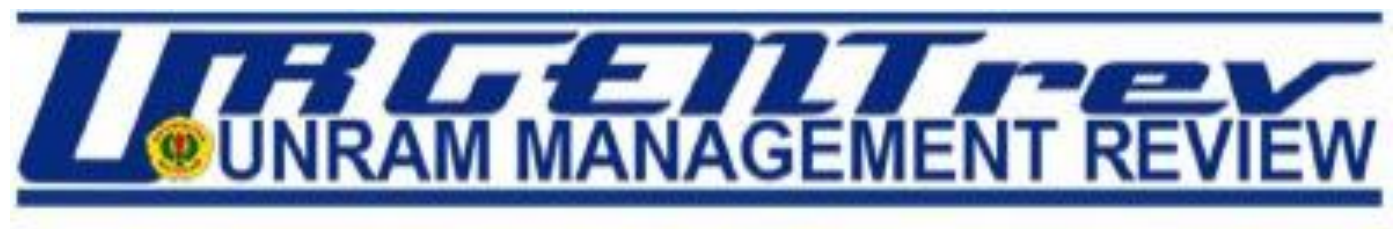

perceived quality berpengaruh signifikan terhadap Minat Beli. Menurut Keller (1998) dan Aaker (1991) dalam Magdalena (2004) menyatakan bahwa, persepsi kualitas dapat didefinisikan sebagai persepsi konsumen terhadap keseluruhan kualitas, atau keunggulan relatif dari sebuah produk atau jasa terhadap alternatifalternatif yang relevan sesuai dengan tujuan yang ingin dicapai. Dari jawaban responden berdasarkan pernyataan mengenai smartphone OPPO memiliki performa kinerja yang baik, memiliki layanan yang baik, daya tahan yang lama dari segi produk, keunggulan produk yang konsisten, memiliki fitur-fitur yang lengkap, spesifikasi yang sesuai dengan yang ditawarkan, dan memiliki kualitas yang lebih baik dari smartphone lainnya memiliki kesan yang baik. Responden memiliki persepsi terhadap keseluruhan kualitas atau keunggulan suatu produk, sehingga jika persepsi konsumen terhadap kualitas suatu produk baik maka produk tersebut akan disukai. Hasil penelitian ini didukung oleh penelitian Akhmadi (2019) mengenai "Pengaruh negara asal, citra merek dan persepsi kualitas terhadap minat beli smartphone OPPO pada mahasiswa perguruan tinggi negeri di Kota Makassar", menyatakan bahwa persepsi kualitas berpengaruh siginifikan dan positif terhadap minat beli”.

Berdasarkan Tabel di atas bahwa koefisien determinasi, dapat dilihat bahwa $\mathrm{R}$ Square menunjukkan nilai sebesar 0,336 atau sebesar 33,6\%. Nilai tersebut menunjukan bahwa pengaruh variabel Country Of Origin, Brand Image dan Perceived Quality terhadap Minat Beli adalah $33,6 \%$. Sedangkan sisanya (100\% $33,6 \%)=66,4 \%$ dijelaskan oleh variabel lain di luar variabel penelitian yang tidak di masukkan ke dalam model penelitian ini.

\section{KESIMPULAN}

1. Terdapat pengaruh signifikan Country Of Origin terhadap minat beli. Artinya semakin baik Country of Origin(persepsi seseorang terhadap negara asal
Selanjutnya berdasarkan uji kelayakan model (uji F) yang telah diolah dalam penelitian ini,di dapatkan hasil sebagai berkut :

Tabel 3 Hasil uji kelayakan model (uji F)

\begin{tabular}{|l|r|l|l|l|}
\hline Model & Df & $\begin{array}{l}\text { F } \\
\text { Tabel }\end{array}$ & $\begin{array}{l}\text { F } \\
\text { hitung }\end{array}$ & Sig, \\
\hline Regression & 3 & 2,466 & 18,725 &, $000^{\mathrm{b}}$ \\
\hline Residual & 111 & & & \\
\hline Total & 114 & & & \\
\hline
\end{tabular}

Berdasarkan tabel di atas terlihat bahwa $\mathrm{F}$ hitung sebesar 18,725 dengan probabilitas signifikan sebesar 0,000 yang berarti nilai probabilitas signifikan <0,05. Sedangkan hasil yang diperoleh dari $\mathrm{F}$ tabel dengan df $1=3$ dan df $2=111$ pada $a=0,05$ sebesar 2,466. Ini artinya $\mathrm{F}$ hitung $>\mathrm{F}$ tabel $(18,725>2,466)$ maka dari itu dapat disimpulkan semua variabel independen (Country Of Origin, Brand Image dan Perceived Quality) layak untuk menjelaskan variabel dependen yang dianalisis.

Tabel 4 Model Summary

\begin{tabular}{|c|c|c|c|c|}
\hline Model & $\mathrm{R}$ & $\begin{array}{c}\mathrm{R} \\
\text { Square }\end{array}$ & $\begin{array}{l}\text { Adj R } \\
\text { Square }\end{array}$ & $\begin{array}{l}\text { Std. Error of } \\
\text { the Estimate }\end{array}$ \\
\hline 1 &, $580^{2}$ &, 336 & ,318 & 2,279 \\
\hline \multicolumn{5}{|c|}{$\begin{array}{l}\text { a. Predictors: (Constant), PERCEIVED } \\
\text { QUALITY, BRAND IMAGE, COUNTRY OF } \\
\text { ORIGIN }\end{array}$} \\
\hline
\end{tabular}

sepertiinovasi, kemajuan teknologi, desain produksi, kreativitas, kualitas, reputasi merek yang baik dan citra negara asal sebagai negara majumaka semakin tinggi minat beli smartphone OPPO.

2. Tidak terdapat pengaruh signifikan brand image terhadap minat beli. Citra merek OPPO dirasa belum cukup kuat untuk mendorong responden untuk melakukan pembelian, dikarenakan responden saat ini tidak menekankan pada merek tetapi cenderung pada faktor lain seperti negara asal dari merek smartphone dan kualitas dari smartphone tersebut .

3. Terdapat pengaruh signifikan perceived quality terhadap minat beli.Artinya semakin baik Perceived Quality (persepsi 


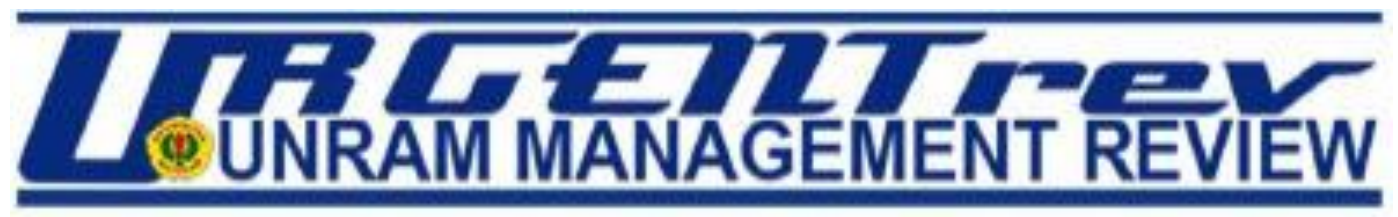

seseorang terhadap keseluruhan kualitas atau keunggulan suatu produk yang meliputi kinerja, pelayanan, ketahanan, karakteristik produk, kesesuaian dengan spesifiksi dan kualitas produk yang dirasakan) maka semakin tinggi minat beli smartphone OPPO.

\section{DAFTAR PUSTAKA}

Aaker, David.A. 1997, Manajemen Equitas Merek, Spektrum. Jakarta, Indonesia.

Abdurachman, Ujianto. 2004. Analisis Faktor-Faktor yang Menimbulkan Kecenderungan Minat Beli Konsumen Sarung (Studi Perilaku Konsumen Sarung di Jawa Timur). Jurnal Manajemen \& kewirausahaan Vol. 6, No.1, Maret 2004.

Achadi, Abu \& Narbuko, Cholid. 2012. Metode Penelitian. Jakarta: BumiAksara.

Akhmadi .2019. "Pengaruh negara asal, citra merek dan persepsi kualitas terhadapminat beli smartphone OPPO pada mahasiswa perguruan tinggi negeri di Kota Makassar"

Assael, Henry. 2002. Consumer Behavior and Marketing Action. 4th Edition, Boston: PWS-Kent Publishing Company.

Assael, H. 2004. Consumer Behaviour: A Strategic Approach. New York: Houghton Mifflin.

Desi Arista, 2011. Analisis pengaruh iklan, kepercayaan merek, dan citra merek terhadap minat beli konsumen. Vol. 13, No. $1: 1-44$.

Dinata, Jovita S. Srikandi Kumadji dan Kadarisman Hidayat. 2015. Country of Origin dan Pengaruhnya Terhadap Persepsi Kualitas dan Minat Beli iPad di Indonesia. Jurnal Administrasi Bisnis (JAB), Vol. 25, No. 1 : 1-8.

Durianto, Sugiarto dan Tony Sitinjak, 2001. Strategi Menaklukkan Pasar Melalui Riset Ekuitas dan Perilaku Merek, PT. Gramedia Pustaka Utama, Jakarta.
Ferdinand, Augusty. 2014. Metode Penelitian Manajemen. BP Universitas Diponegoro. Semarang.

Ghozali, Imam. 2009. Aplikasi Analisis Multivariate Dengan Program SPSS. Semarang: Badan Penerbit Universitas Diponegoro, Vol.100125.

Ghozali, Imam. 2016. "Aplikasi Analisis Multivariate dengan Program IBM SPSS23Update PLS Regresi".Edisi 8. Badan Penerbit Universitas Diponegoro.Semarang

Hseish,M..H.,Pan,,S.L.,Setiono,R. 2004. Product, corporate and country of origin dimentionsand purchase behavior: A multicountry analysis. Journal of the Academic of Marketing Science.32(3):251-270.

Indrayani, Linda dan I Nyoman Nurcaya. 2014. Peran Persepsi Kualitas Produk dalam Memediasi Pengaruh Gaya Hidup Terhadap Niat Beli Handphone Samsung Galaxy di Kota Denpasar. E-Jurnal Manajemen Universitas Udayana, Vol. 3, No. 4 : 1-17.

Indriantoro, Nur and Bambang Supomo. 2014. METODE Penelitian Bisnis Untuk Akuntansi \& Manajemen. Edisi 1. Cetakan ke-12. Yogyakarta: BPFE.

Kaynak, E., Kucukemiroglu, O., and Hyder, A.S. 2000. Consumers' Country-Of-Origin(COO)

Perceptions of Imported Products in a Homogenous Less-Developed Country. European Journal of Marketing, Vol. 34, No. 9/10: 12211241.

Keller, Kevin Lane. (1998). Strategic Brand Management, Building, Measuring, and Managing Brand Equity. New Jersey: Prentice Hall.

Kementerian Komunikasi dan Informatika Republik Indonesia. Indonesia Raksasa Teknologi Digital Asia. 2015. 
King, L.A. 2011. Psikologi Umum Sebuah Pandangan Apresiatif. Jakarta: Salemba Humanika.

Kotler Philip. Gary Amstrong. 2008. Prinsip - Prinsip Pemasaran. Edisi Kedua belas.Erlangga.

Kotler, Philip \&Keller. (2008). Manajemen Pemasaran. Edisi Ketigabelas. Jilid 1. Jakarta: Erlangga.

Kotler dan Keller. 2009. Manajemen Pemasaran. Jakarta: Erlangga.

Kotller Philip, Amstrong Garry. 2013. Prinsip Pemasaran. Edisi Ke 12. Airlengga.

Kotller Philip, Keller. 2012. Manajemen Pemasaran. Jilid1. Edisi Ke 12. Jakarta: Erlangga.

Lin, C.H., and Kao, D.T. 2004, The Impacts of Country-of-Origin on Brand Equity. The Journal of American Academy of Business, Cambridge.

Malhotra, Naresh K. "Riset Pemasaran". PT Indeks, Jakarta, 2011.

Masaoka dan Rahayuda. 2016. Peran Brand Image dalam memediasi country of origin terhadap purchase intention. Jurnal Manajemen.

Mendrofa, Yoseph Baniader. 2012. Effect of Product Knowledge and Brand Image to Purchase Intention with HP Laptop Brand Price Discounts as Variables Moderated in Surabaya. Jurnal Ilmiah Mahasiswa Manajemen(JUMMA), Vol. 1, No. 4. 1-6.

Michael R. Czinkota, Ilkka A. Ronkainen. 2001. International Marketing. Harcourt College Publishers.

Nazir, Moh. 2005. Metode Penelitian. Jakarta: Ghalia Indonesia.

Oppo Website. Tentang Oppo. 2021. http://www.oppo.com/id/about-us

Oliver, Sandra. 2006. Strategi Public Relations. Jakarta: Erlangga.

Permana, Magyar Slamet dan Jony Oktavian Haryanto. 2014. Pengaruh Country of Origin, Brand Image dan
Persepsi Kualitas terhadap Intensi 365-380.

Rafida, Saino Veni. 2015. Pengaruh Country of Origin terhadap Minat Beli dengan Perceived Quality sebagai Variabel Intervening pada Pengunjung Artomoro Selluler di Madiun. Jurnal Pendidikan Tata Niaga (JPTN), Vol.3, No. 2. : 1-10.

Rangkuti, Freddy. 2004. Manajemen Persediaan: Aplikasi di Bidang Bisnis.Jakarta: Grafindo Persada.

Rizky, M.F. \& Yasin, H. (2014), Pengaruh Promosi dan Harga Terhadap Minat Beli Perumahan Obama PT. Nailah Adi Kurnia Sei Mencirim Medan. Jurnal Manajemen \& Binsis, Vol. 14(2), hal. 135-143.

Sanyal, Shamindra Nath., dan Saroj, Kumar Datta. 2011. The Effect of Country Origin on Brand Equity: An Empirical Study on Generic Drugs, Journal Of Product \& Brand Management, Vol. 20, No. 2: 130140.

Schiffman dan Kanuk. 2007. Perilaku Konsumen, Edisi 2, Jakarta: PT. Indeks Gramedia.

Schiffman dan Kanuk. 2009. Perilaku Konsumen Edisi 7. Jakarta: Indeks.

Silalahi, Ulber. 2010. Metode Penelitian Sosial. Jakarta: Refika Aditama.

Simamora, Henry. 2000. Manajemen Pemasaran Internasional. Edisi Kedua.Jakarta: Salemba Empat.

Simamora, Bilson. 2004. Panduan Riset Perilaku Konsumen. Jakarta: Gramedia Pustaka Umum

Siregar. Syofian. 2014. Metode penelitian kuantitatif dilengkapi dengan perbandingan perhitungan manual dan SPSS. Jakarta: Kencana.

Siregar, Syofian. 2016. Statistika Deskriptif untuk Penelitian Dilengkapi Perhitungan Manual dan Aplikasi SPSS Versi 17. Jakarta: PT Raja Grafindo Persada

Sugiyono. (2014). Metode Penelitian Pendidikan Pendekatan Kuantitatif, 


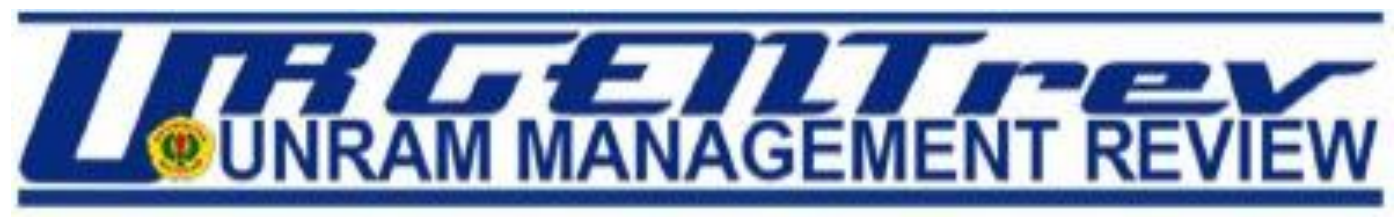

Vol. 1 No. 1 Oktober 2021

Kualitatif, dan R\&D. Bandung: Alfabeta.

Suharyadi dan S.K. Purwanto 2013. Statistika untuk Ekonomi dan Keuangan Modern. Edisi ke-2. Jakarta: Salemba Empat.

Suliyanto. 2014. statistika nonparametrik: dalam statistik penelitian. Andi publisher. Yogyakarta

Sutantio, Magdalena, 2004, "Studi Mengenai Pengembangan Minat Beli Merek Ekstensi (Studi Kasus Produk Merek Sharp di Surabaya)", Jurnal Sains Pemasaran Indonesia, Vol. III, No. 3, 243-266

Wahyu Setianingsih. 2016. "Pengaruh Country Of Origin, Brand Image Dan Pesepsi Kualitas Terhadap Minat Beli Opppo SmartPhone (Studi Kasus Pada Mahasiswa Strata Satu Fakultas Ekonomi Universitas Negeri Yogyakarta)

Yanthi, K. P., \& Jatra, I. M. (2015). Pengaruh Country of Origin, Brand Image dan Perceived Quality terhadap Minat beli sepeda motor honda beat di kota Denpasar. E-Jurnal Manajemen Unud, 4(11), 3852-3881.

Yasin, Norjaya Mohd., Mohd Nasser Noor dan Osman Mohamad. 2007. Does Image Of Counry-Of-Origin Matter To Brand Equity? Journal Of Product \& Brand Management Vol. 16, No.1: 38-48. 